\title{
48. SALADO-VINORAMA SUBMARINE SLIDE AND TURBIDITY CURRENT OFF THE SOUTHEAST TIP OF BAJA CALIFORNIA ${ }^{1}$
}

\author{
D. G. Moore and J. R. Curray, Scripps Institution of Oceanography, La Jolla, California \\ and \\ G. Einsele, Geologisches Institut der Universität Tübingen, Tübingen, Federal Republic of Germany
}

\begin{abstract}
Site 474 (water depth $3023 \mathrm{~m}$ ) is on oceanic crust southeast of the tip of Baja California. The crust is overlain by about 500 meters of diatomaceous mud and mudstone turbidites. A redeposited unit in the upper part of the section (21-97 m) comprises muds, marls, coarse arkose, and conglomerate. Contained fossils are older (NN19) than the underlying sediments (NN20), and indicate shallower, warmer-water deposition than those above or below the unit. Seismic-reflection profiles from site surveys of the adjacent source areas on the dissected continental slope to the northwest show the upper fan valley (above $\sim 2400 \mathrm{~m}$ water depth) of the confluent source canyons (Salado and Vinorama) to be relatively normal in appearance. The midfan valley $(\sim 2500-2850 \mathrm{~m})$, however, appears to have been broadened greatly by sliding of destabilized sediments. Lithology of the displaced unit and seismic structure of the fan valley require a compound sequence of events leading to the re-transport of coarse canyon-head and finer mid-fan sediments to the basin floor below to form the discrete slide-flow unit. We believe this sequence of events comprised a slow-moving flow of coarse clastic debris from canyon source to upper mid-fan, widespread failure of over-pressured impermeable muds of the mid-fan, and a resulting fluid mixed-debris flow and turbidity current that rapidly displaced most of the combined sediments to their present position. Turbidity currents generated with the debris flow followed and may have transported sediments over a wide area.
\end{abstract}

\section{INTRODUCTION}

Deep-sea drilling and associated site-survey seismicreflection profiling southeast of the tip of Baja California at Sites 474, 475, and 476 (Fig. 1A) provided a unique opportunity both to sample a deep-basin submarine debris-flow-turbidity-current deposit and to study seismic transects of the deposit and its source and transit areas on the adjacent dissected continental slope. Seismic-reflection studies of mass-flow structures are documented in many regions of the world oceans (Moore, 1977; Embley and Jacobi, 1977), and slide and debris-flow masses have been described from several DSDP sites (Lancelot, Winterer, et al., 1977; von Huene, Nasu, et al., 1978; Sibuet, Ryan, et al., 1979, for example), but these investigators were unable to examine both the source and the deposit.

Site 474 is on oceanic crust overlain by about 500 meters of predominantly diatomaceous mud and mudstone turbidites (Fig. 2A, B). In the upper part of the section $(21-97 \mathrm{~m})$ is a redeposited unit of muds, marls, coarse arkose, and conglomerate, having fossils indicating warmer, shallower-water deposition than those above or below, and an age (NN19) greater than that of the underlying sediments (NN20). The upper part of the unit comprises diatomaceous clayey silt, silty to sandy mud and lumps of sand and sandy mud. Below, but not contiguous with these, are about 30 meters of arkosic sand to cobble conglomerate. The latter is a fining-upward bed of grain-supported clasts and a small amount

\footnotetext{
${ }^{1}$ Curray, J. R., Moore, D. G., et al., Init. Repts. DSDP, 64: Washington (U.S. Govt. Printing Office).
}

of nannofossil-bearing fine matrix, moderately sorted. Included in the section are clasts of mollusk debris and bryozoan fragments, benthic foraminifers, and calcareous algae, all of nearshore origin. The multiple sources of this redeposited unit and the complex sequence of events leading to its final emplacement are the subjects of this paper.

\section{REGIONAL BATHYMETRY-CANYON AND DISTRIBUTARY SYSTEM}

In view of the regional bathymetry (Fig. 1B), it is clear that most of the terrigenous mudstone turbidites cored at Site 474, and probably the components of the redeposited unit under discussion as well, were derived from the submarine canyon systems to the northwest of the site, and probably mainly from the confluent Salado and Vinorama Canyons. The drainage system for these latter two canyons comprises a complex of seven principal tributaries cut into the steep granite rock of the upper slope and narrow shelf and extending down to a depth of about 1600 meters. From this depth, the two canyons continue basinward without further tributaries, to their confluence at about 1500 meters. Beyond the confluence, the drainage initially trends almost directly down the slope to 2500 meters. From there it curves around the north end of a ridge with a 2100-meter peak, then down through a gap at about 2900 meters into the base-of-slope basin where we drilled.

Salado, Vinorama, and Los Frailes Canyons are all located off major arroyos on shore. Los Frailes extends from deep water across the 3-km-wide shelf to near the surf zone; Vinorama ends near the outer shelf edge; and Salado slightly indents the shelf. All of the canyons are known to be very sandy in their upper reaches. Drainage 


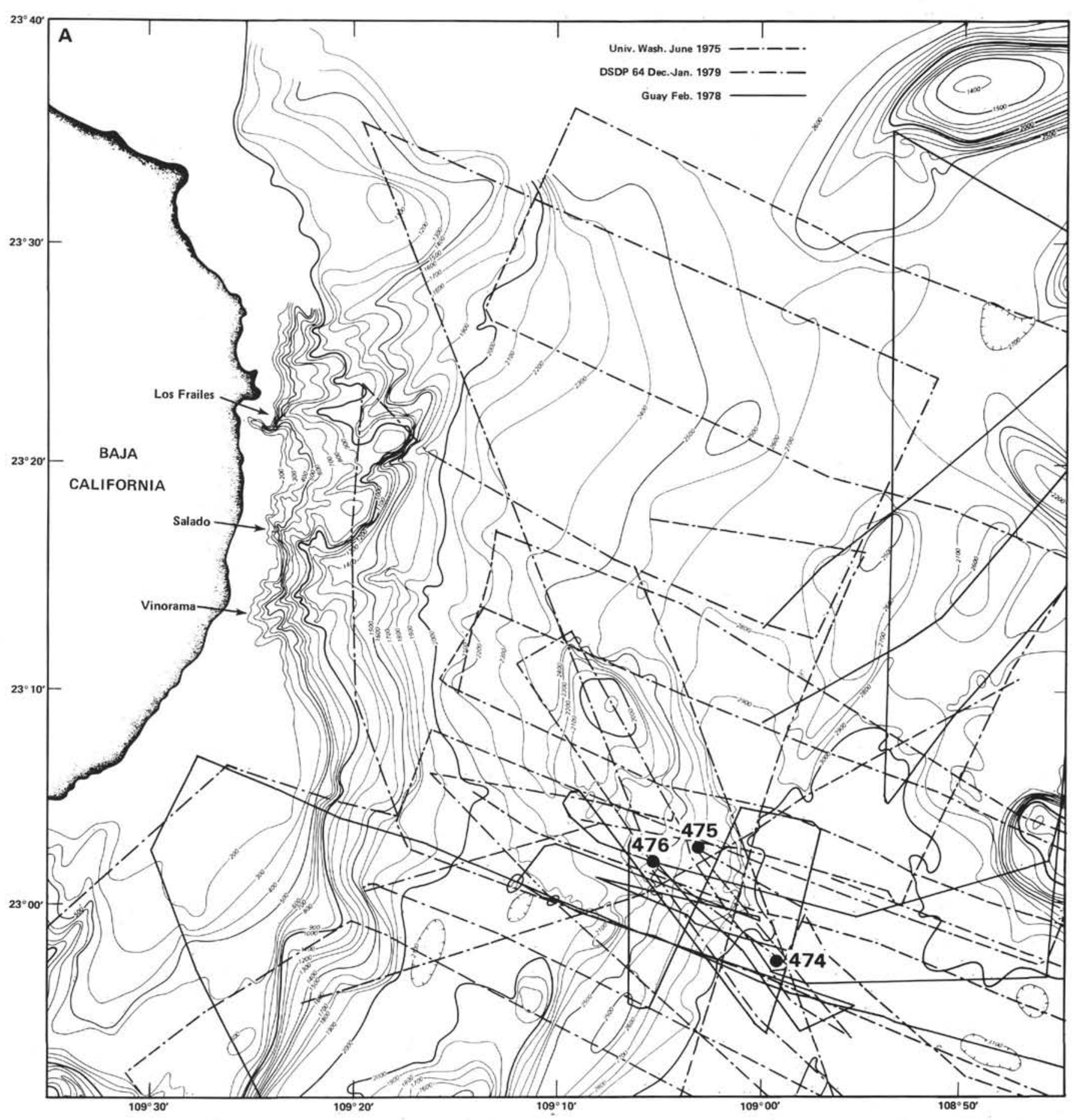

Figure 1. A. Bathymetric map of the region off the southeast tip of Baja California, showing seismic reflection tracks in the vicinity of Sites 474 , 475, and 476. B. Detail of submarine canyons cutting the continental slope. Los Frailes Canyon is to the north, and the Salado and Vinorama Canyon systems are the southernmost of the group. These latter two canyons join between 1400 and 1500 meters. The resulting drainage forms a fan valley that trends downslope to the east, turns south at about 2800 meters, and empties onto the basin plain north of Site 474 .

from the arroyos and longshore sand transport at Pleistocene low sea-level stands have combined to introduce coarse arkosic sands and gravels into the canyon heads. Shepard and Dill (1966, pp. 119-127) reported that a box core from the head of Salado Canyon at a depth of 146 meters recovered graded fine sand to gravel, and that photos show rounded cobbles up to $15 \mathrm{~cm}$ in diam- eter incorporated into the sandy fill of Los Frailes Canyon at a depth of 130 meters.

Studies of the Los Frailes Canyon (Shepard and Dill, 1966) showed that the rock-walled canyon extends to about 1600 meters, where sediments of the upper fan onlap the rock slope. A transect of Salado and Vinorama Canyons at about the 1500 -meter depth with Glo- 


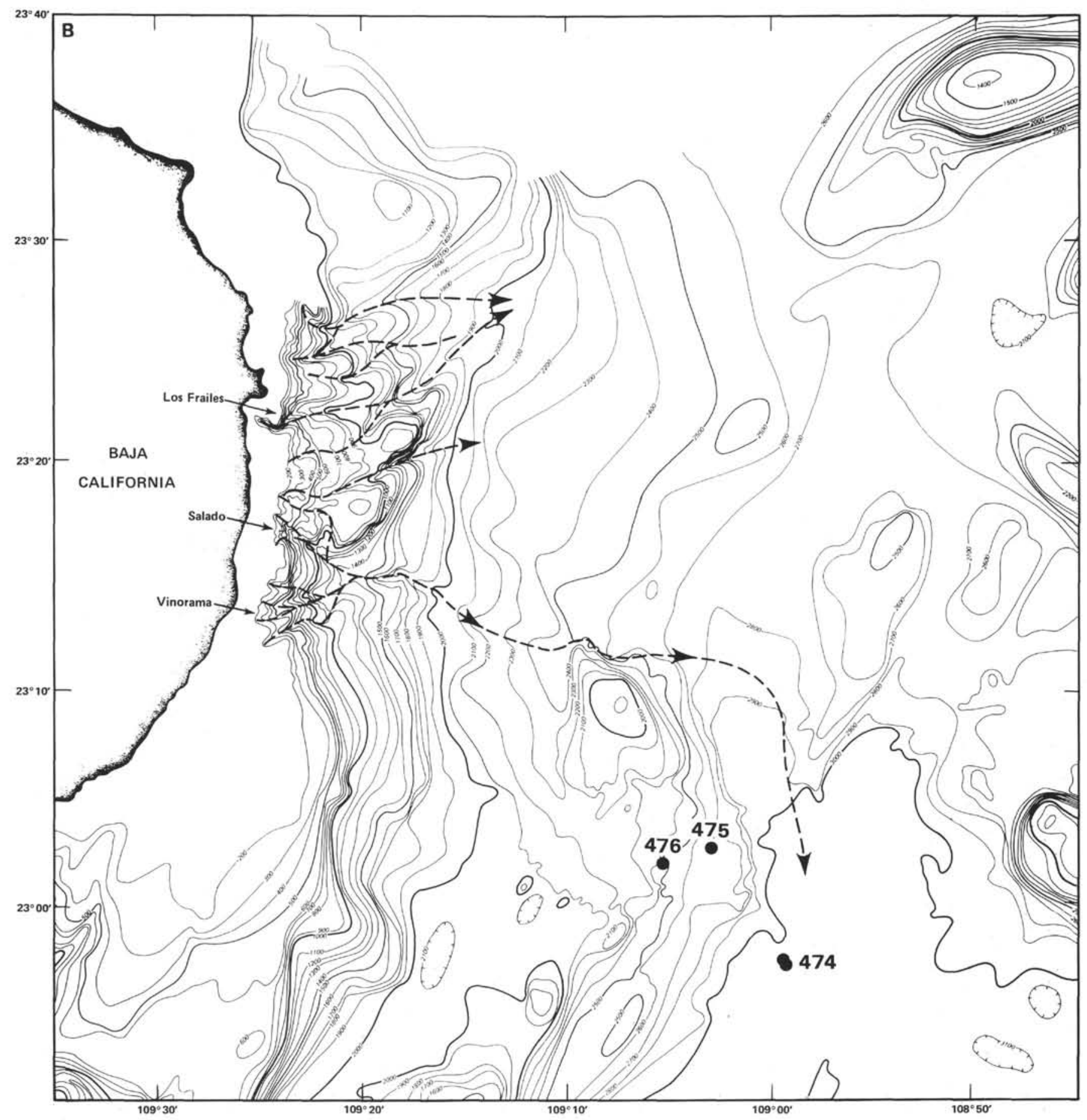

Figure 1. (Continued).

mar Challenger's air-gun seismic-reflection system verifies that the level of transition from canyon to fan is below this depth. If the canyon fan contact depth of Salado and Vinorama Canyons is similar to that of Los Friales, then the drainage system from 1600 meters to the drill site includes a small deep-sea fan (Figs. 1B and $3)$. The fan has but a single active channel, which is typical of other well-surveyed, much larger fans (Curray and Moore, 1974), and the turbidites cored at Site 474 were deposited on the distal end of the fan. The channel itself is, however, atypical, as we shall discuss further.

\section{SEISMIC-REFLECTION TRANSECTS}

Seismic-reflection profiling coverage in the area by Glomar Challenger and other vessels are shown in Figure 1A. Transects of the University of Washington site-survey cruise (TTO99; Lewis et al., 1975) cross the fan valley of the confluent Salado-Vinorama Canyons at four localities (Figs. 4-7). Other Scripps site-survey transects (Guaymas in 1978; Moore et al., 1978) cross the basin plain or distal fan in the vicinity of Site 474 . The uppermost of the sections across the distributary (Section A- 


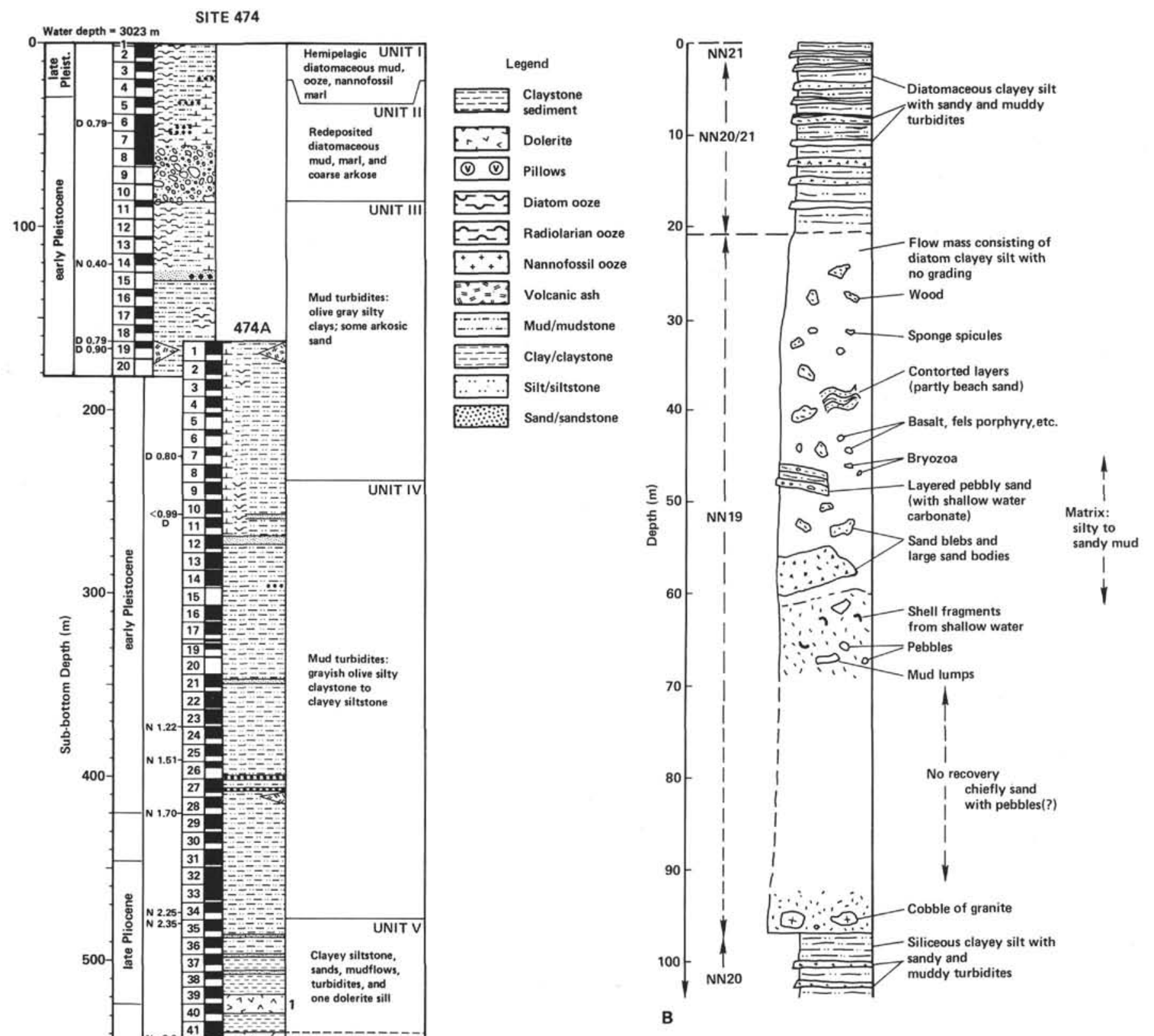

Figure 2. A. Lithologic section of Site 474. B. Detail of slide flow mass at Site 474.

$\mathrm{A}^{\prime}$, Fig. 4) crosses the upper fan valley at about 2200 meters. It displays a well-developed fan valley with natural levees and well-stratified fan sediments sloping away from each side of the valley. The valley appears to have been at approximately the same position as at present throughout its growth, with relatively little lateral migration. The valley has a typical upper-fan sectional profile and does not appear to have been altered significantly by a mass movement of sand that we suggest passed through this section of the upper fan valley. Three transects crossing the valley below this locality at thalweg depths of about 2600,2850 , and 2945 meters (Sections B-B', C-C', and D-D', Figs. 5, 6, 7), however, show the valley to be modified substantially from a typical mid-fan valley configuration. Section B-B' is notable for the scarp on the upstream side, the broad cross-section and hummocky floor of the valley, and the partial destruction of internal reflectors beneath the 


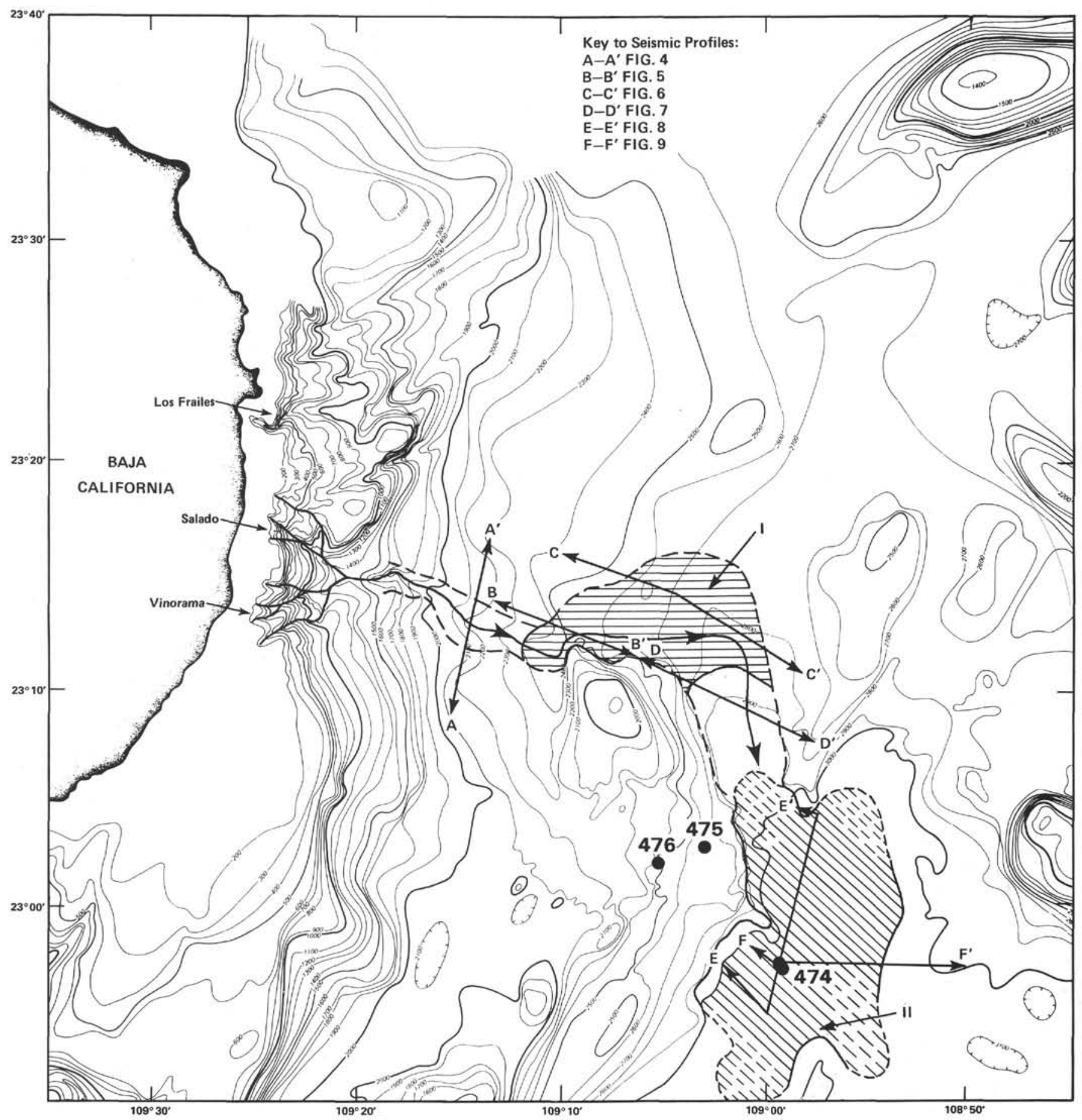

Figure 3. Salado and Vinorama Canyons and deep-sea fan. Arrows show locations of illustrated seismic profiles. Thalweg of canyon tributaries and fan valley shown by solid line with flow arrows. Heavy dashed lines delineate fan-valley boundaries, and Area I (horizontal hachures) shows region where high-velocity debris flow probably originated; Area II (diagonal hachures) shows present position of slide mass. Boundaries of the slide flow mass are shown solid where topographically bounded and dashed where thinning out. Profiles A-D are from University of Washington Cruise TTO99 (Lewis et al., 1975); profiles E and F are from S.I.O. Guaymas 1978 Cruise (Moore et al., 1978).

hummocky floor. These features strongly suggest that a slide here has broadened the valley by removal of sediments below the scarp. Well-stratified sediments that probably were continuous beneath most of the recorded sub-sea-floor section prior to the slide have been partially destroyed by a smaller amount of associated mass downslope movement. Remnants of stratified structure are visible beneath the southeastern valley floor and in the northwestern end of the transect. Section $\mathrm{C}-\mathrm{C}^{\prime}$ cuts across the outside of a broad turn in the valley. This section again shows a scarp on the upslope valley wall and evidence of broadening of the valley by detachment sliding, and partial destruction of the sub-valley-floor stratification by less-intense mass movement. Undisturbed 


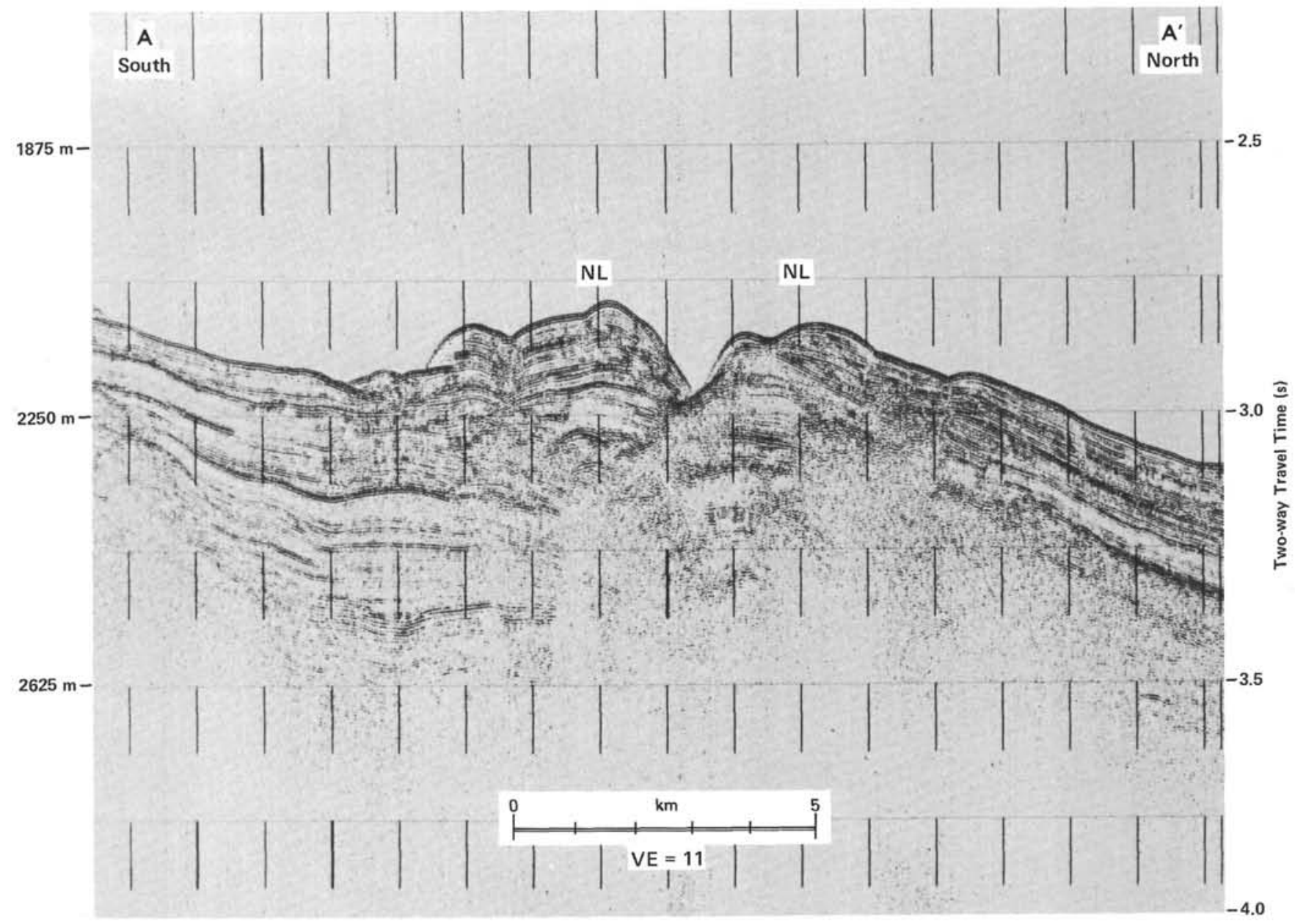

Figure 4. Seismic profile $\mathbf{A}-\mathbf{A}^{\prime}$ crossing well-developed fan valley on upper fan. Natural levees (NL) are built 173 meters above valley floor. The valley at this level is typical of those formed by turbidity currents. It has undergone little lateral migration and does not appear to have been modified by sliding. Figure 3 gives location.

strata can be seen flanking the valley. Section D-D', somewhat farther down-channel and near the debouchment of the valley onto the basin floor, shows no disturbance to sub-valley-floor strata and displays a morenormal profile of a distal-fan valley. Data from the distal fan of the basin plain in the area of Site 474 (Figs. 3, 8 , and 9) show that the seismic section equivalent to the redeposited unit identified in drilling exists as an areally extensive stratigraphic horizon over at least $210 \mathrm{~km}^{2}$. That the unit cannot have been deposited as a discrete slump lobe from a local source is shown also by its abutment against the nearby continental slope. This abutment implies also that the unit must have been deposited as a relatively fluid mass which spread laterally over a wide area after debouching from the deep, broad distributary valley.

\section{SOURCE, PROPERTIES AND EMPLACEMENT MECHANISM OF THE REDEPOSITED UNIT}

To understand the mechanism of transport and deposition of the redeposited unit cored at Site 474 , it is useful to summarize geomorphic and geologic features that must be plausibly explained by theory.
1) The regional bathymetry (Fig. 1) and the shallowwater and warmer-water components of the displaced sediment section (Fig. 2A, B) indicate that the coarse clastic and biogenic components of the slide must have originated near the canyon heads, and the finer sediments from the fan slope region above the distal basin facies.

2) The warm-water shallow-water fauna, bryozoan and benthic foraminifers, and the age greater than those below imply that the sediments of the entire displaced section sampled from 21 to 97 meters (Fig. 2) are the product of a single event or train of events. Diatomaceous muds, marls, and lumps of sandy mud that constitute the upper 55 meters of the redeposited section are not contiguous with the lower arkosic sand and conglomerate, but are included in that section because they contain warmer-water, shallower-water, displaced nannofossil floras of NN19 age. Thus, both the predominantly hemipelagic sediments overlying the displaced unit and the underlying, mainly mud turbidites contain floras that are of younger NN20 age and indicative of deeper-water, colder-water deposition.

3) Seismic transects that cross the fan valley of the confluent Salado-Vinorama canyons display structure 


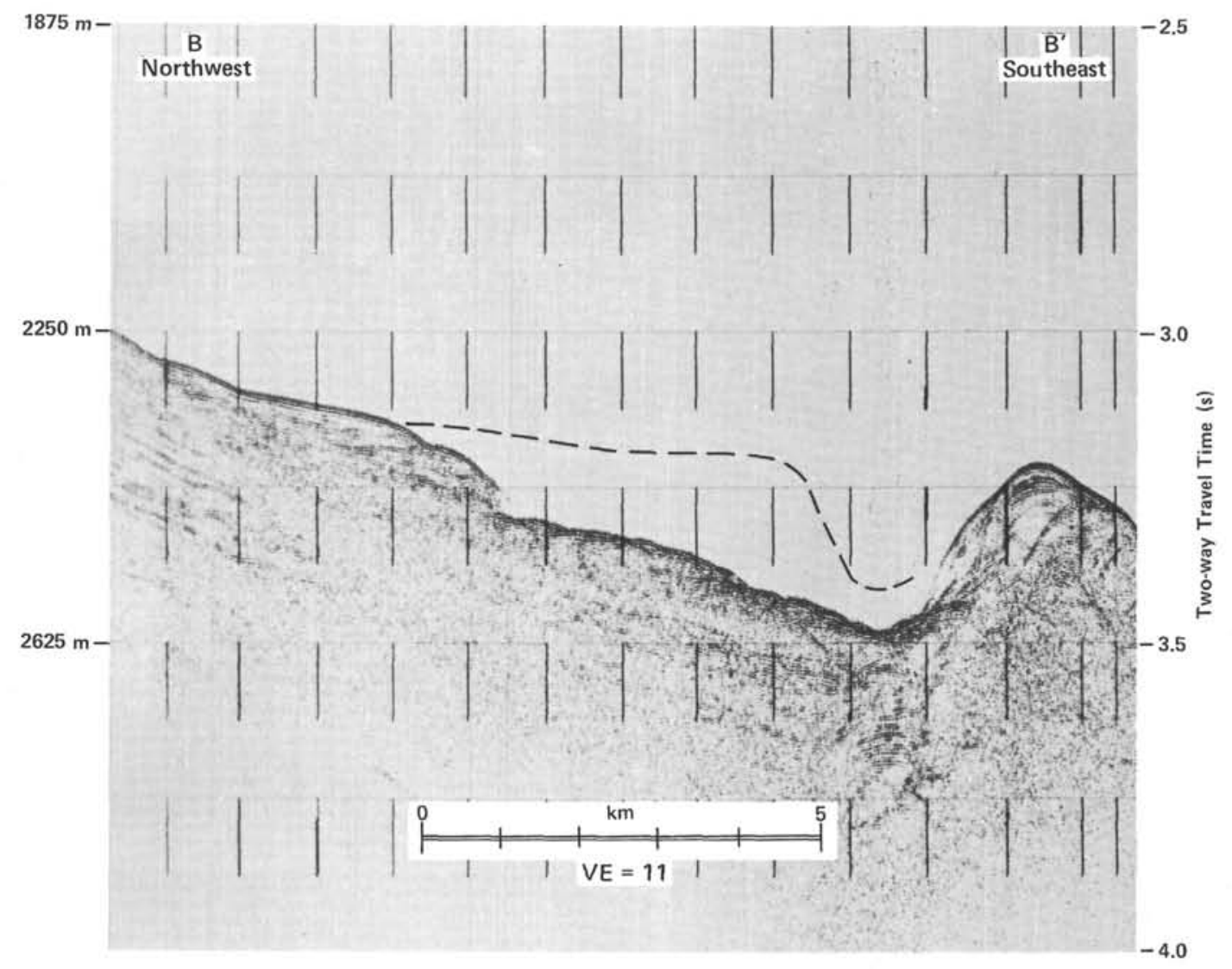

Figure 5. Seismic section B-B' crossing fan valley at thalweg depth of 2610 meters on upper part of mid-fan. The valley here appears to have been significantly broadened and deepened by the slide. The probable pre-slide profile of the valley is indicated by the dashed lines. Note the scarp on the upper northwest side of the broad channel, the hummocky channel floor, and partial destruction of stratification in sediments deep beneath part of the valley, about $3 \mathrm{~km}$ on each side of the scarp, caused by mass movement. Figure 3 gives location.

that implies the following. The fan valley, from the confluence to a depth somewhat below 2400 meters, appears to be relatively unaffected by the hypothetical initial coarse-clastic mass-flow event. The valley from above 2500 meters to about 2850 meters (present thalweg depth) appears to have been the source region of the principal muddy portion of the flow mass. In this region the valley was broadened by sliding of destabilized sediments and the structure of underlying strata was disrupted by less-pronounced movement (Figs. 5, 6). From somewhat above 2945 meters to the depth of basin deposition at about $\mathbf{3 1 1 0}$ meters, there is evidence of typical turbidity-current erosion in the channel, but no disturbance of underlying strata. These seismic data and the known stratigraphy of the redeposited unit suggest that the debris flow was generated at shallower depths, and that-probably together with a trailing turbidity current-it eroded the valley below 2850 meters and spread out onto the distal fan of the basin plain, where deposition occurred. The sequence of events and processes (summarized in Fig. 10) which we now present to explain the origin of the redeposited section in Hole 474 takes into account these limiting elements of known topography, structure, and stratigraphy.

During a period within NN19 time ( 0.4-1.8 m.y.), large amounts of arkosic sand and cobbles were accum- ulating in the upper reaches of the Salado and Vinorama Canyons. The coarseness of these deposits and the present near-shelf-edge position of the canyon heads suggest a period of glacially lowered sea level, cobbles and sand having been introduced directly from a stream source, and other sands brought in from longshore lateral transport. These coarse clastics were transported down the upper, steepest parts of the canyons by local slides, creep, and sand flows (Dill, 1964), while new supplies continued to pour into the canyon heads. These processes were probably very rapid, and the rock-walled canyons soon accumulated a large reservoir of sand and cobbles. During the same period, fine-grained hemipelagic sediments rained onto the mid-slopes and some were intermittently transported down-canyon by turbidity currents to be deposited on the fan below the canyon mouth. In the base-of-slope basin at the position of Hole 474 , meanwhile, the slow deposition of nannofossilbearing siliceous clayey silts and silty clays with occasional mud turbidite cycles continued.

At some time after a large reservoir of coarse clastics had accumulated within the confines of the rock-walled canyon system, there ensued a massive failure of this material that resulted in an extensive sand-and-cobble debris flow. The failure could have been triggered by a large earthquake within this seismically active region, or 


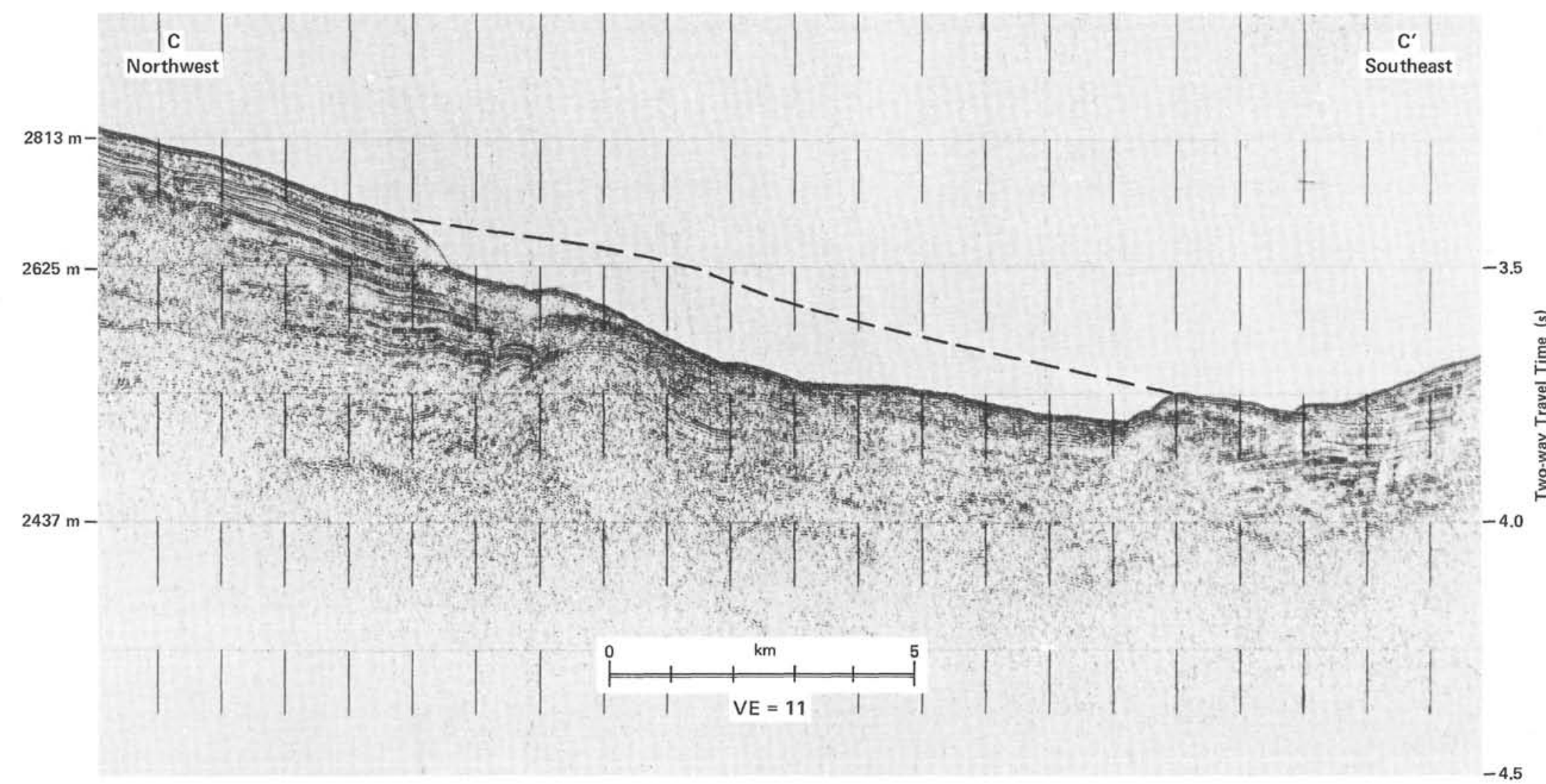

Figure 6. Seismic profile C-C', crossing the outside of a broad turn in the valley on the mid-fan. Removal of sediment by debris flow has broadened the valley and left a scarp on northwest channel wall. A possible original profile is indicated by the dashed line. Less-pronounced mass movement in sediments beneath the channel floor has almost totally destroyed stratification. Figure 3 gives section location. 


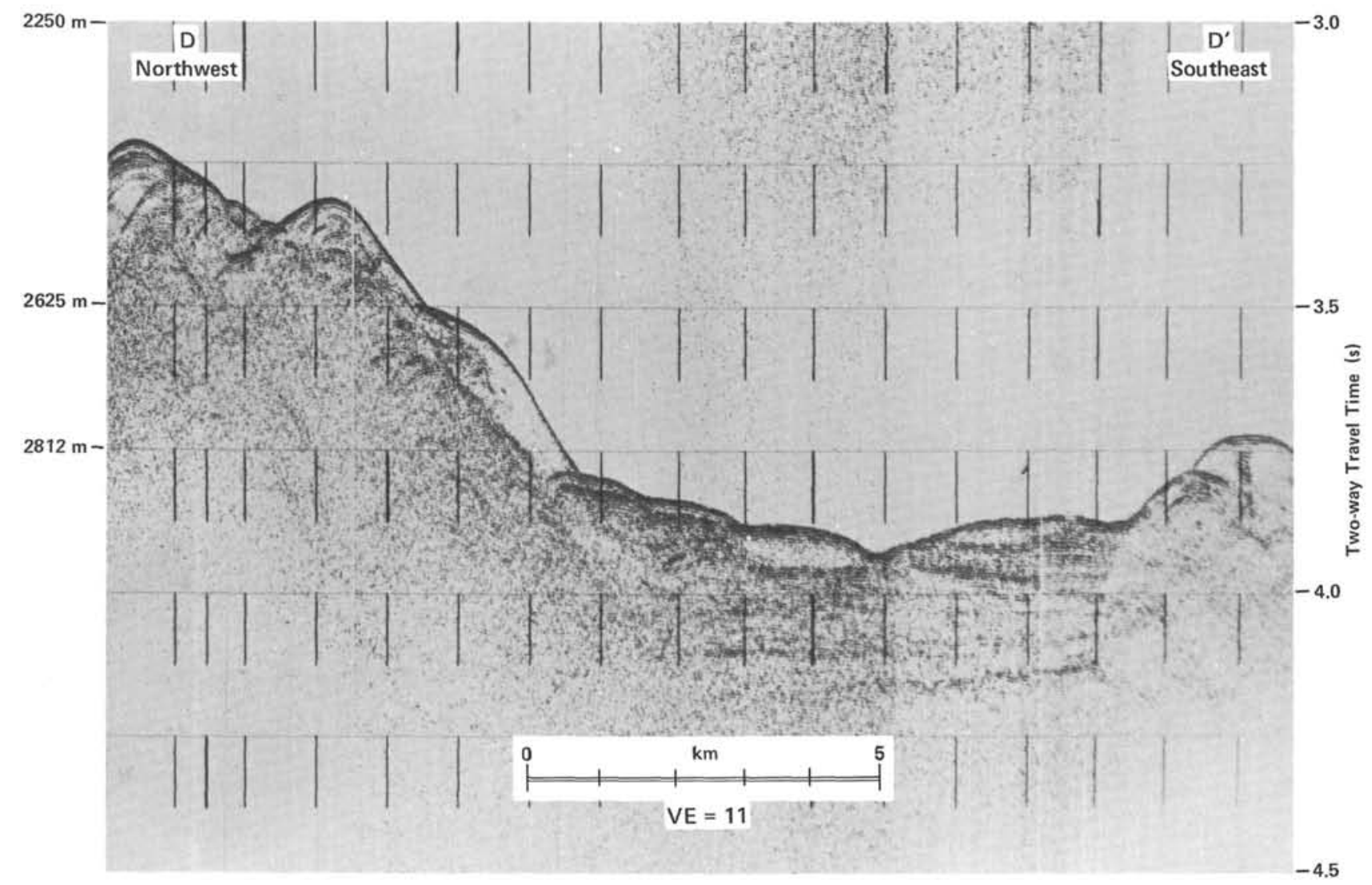

Figure 7. Seismic profile D-D', crossing the broad channel on the uppermost part of the lower fan at 2900 meters. Channel here shows evidence of erosion of shallow strata beneath the channel, but more deeply buried stratification is intact. This implies that the fluid debris flow and turbidity current transited this part of the channel, but originated upslope. Figure 3 gives location.

it could have resulted from a sudden catastropic influx of masses of sand and cobbles into the upper canyon from storm-swollen streams. Whatever the cause, it was unique, and not repeated during numerous intervals of glacially lowered sea level recorded in the sediments of Site 474 . The huge debris flow must have largely drained the canyon reservoir of coarse clastics, probably over a short time-perhaps days or weeks-and transported the material through the steep upper fan valley at relatively slow speeds to flow across the upper fan and onto the much flatter mid-fan. The resulting superposition of a great load of coarse clastics onto the mid-fan in a short time would almost certainly have caused a large slide.The mid-fan source area of the principal, muddy portion of the flow mass lies on the slope near (see Fig. 3 ) and in the same depth range (2400-2850 m below sea level) as Sites 475 and 476 (2631 m and $2403 \mathrm{~m})$. Therefore, it can be expected that sediment type and physical properties of the dislocated sediments prior to their disturbance were similar to those at these sites (Fig. 11). The physical properties are relevant in two ways:

1) As a factor controlling the initiation of a second mass flow event.

2) For comparison with the properties of the final displaced deposit. Regarding (1): If a sliding plane at a median depth of 75 meters below sea floor is assumed (height of scarps in Figs. 4 and 5), the clayey silts and silty clays above this failure plane had properties as follows (Fig. 10, and see also site chapters, this volume, Pt. 1, and Einsele, this volume, Pt. 2):

porosity: 70 to more than $80 \%$

"wet" water content: 50 to more than $60 \%$

wet-bulk density: 1.3 to $1.5 \mathrm{~g} / \mathrm{cm}^{3}$

vane shear strength: $60-65 \mathrm{kPa}$

Clearly a sudden loading of these highly porous and loosely packed sediments would initiate high excess pore pressure, loss of shear strength, and fluidization of the affected slope deposits. The poor permeability of the clayey silts or silty clays prevents a rapid escape of pore waters. The abrupt loss of strength, in turn, triggered a large, very fluid, and rapidly moving slide in the zone from about 2450 to 2850 meters present thalweg depth (Fig. 3). The coarse clastics of the initial flow from the canyon thus were provided with a mechanism for transport through the lower fan valley and into the basin. With the initiation of the slide, the coarse clastics may have ridden on the muddy, flowing mass. They would soon have been incorporated into the flowing slide to form a mixed debris flow (a matrix-supported flow). Finally they must have sunk to near the basal part of the flow mass as it came to rest. Deposition occurred over a wide area on the lowermost fan of the basin floor after debouchement from the valley confines. The contents of turbidity currents associated with the mass gravity flows were then deposited atop the now-widespread displaced strata (i.e., the section between 21 and $60 \mathrm{~m}$ ). Subse- 


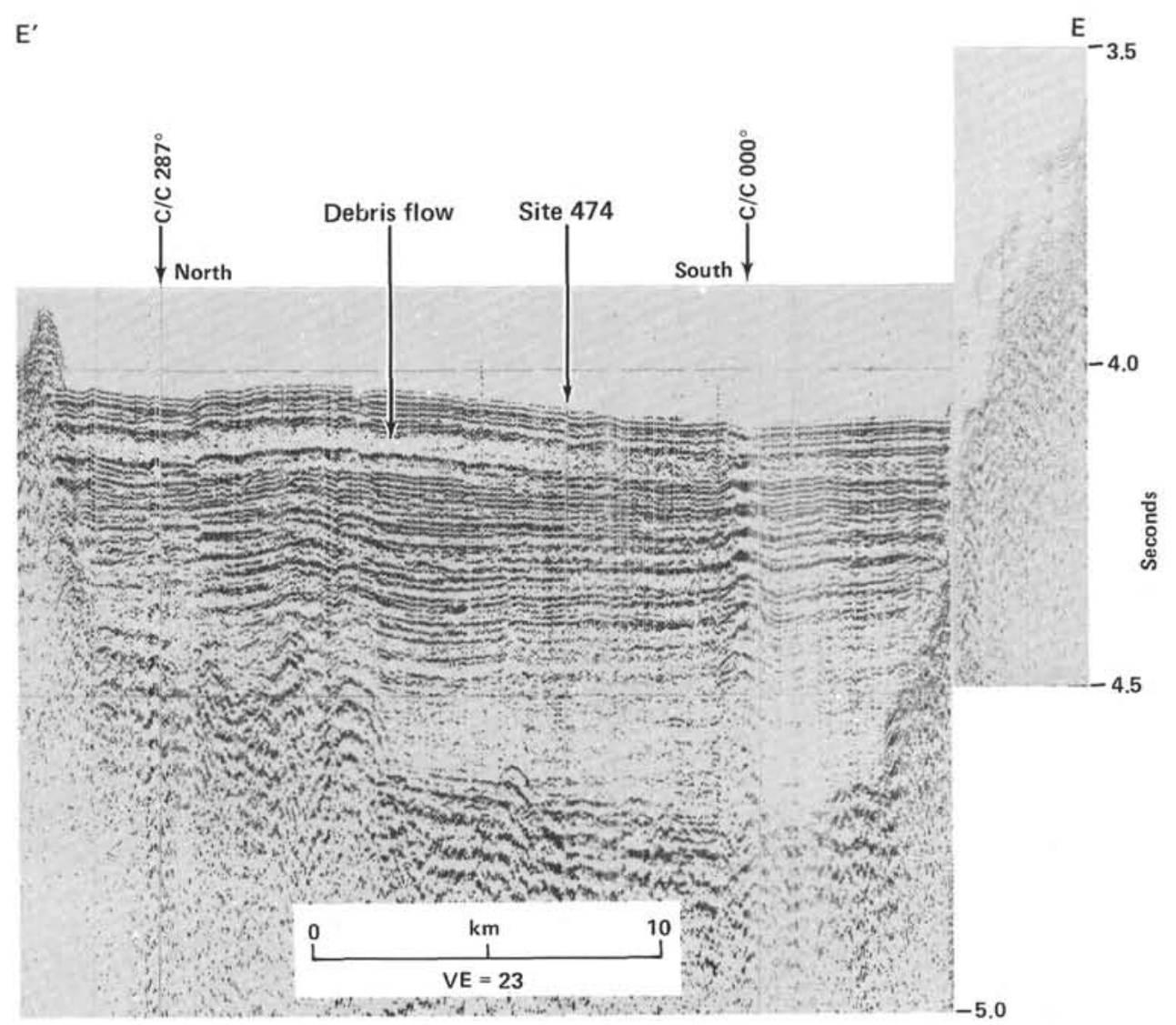

Figure 8. Seismic profile E-E', extending down the lower fan from the fan-valley debouchment through Site 474 and beyond. The redeposited section of debris flow is clearly shown as a non-stratified zone in the seismic record, extending beyond the drill site and abutting the base of the continental slope to the west. Figure 3 gives location.

quently, younger contemporaneous hemipelagic diatomaceous silts and muds released from suspension in deeper water flows covered the displaced sediments.

The redeposited section differs considerably in its mass physical properties from the muds of the source area (Fig. 11). The somewhat reinterpreted data points (see Site 474 site chapter, this volume, Pt. 1) show a marked decrease in porosity $(50-65 \%)$ and "wet" water content $(30-40 \%)$ and an increase in wet-bulk density $\left(1.6-1.8 \mathrm{~g} / \mathrm{cm}^{3}\right)$. Below the redeposited section of Site 474 , all data again compare well with those of the slope sites at the same depth below sea floor.

The change in physical properties of the debris flow at Site $\mathbf{4 7 4}$ is caused by two factors: (1) the admixture of coarse-grained material (mainly sand) from the head of the canyons as described earlier; (2) the process of mass flow itself, wherein some pore water is released, causing the redeposited material to be more densely packed than before its displacement.

The subsequent burial of the mass flow under 20 meters of younger, normal basinal sediments and the resulting slight compaction do not play a great part in the modification of physical properties.

\section{DISCUSSION}

The mode of transport of marine sands and conglomerates to the deep-sea floor has been widely discussed in the literature (see Stanley and Unrug, 1972; Middleton and Hampton, 1973 for summaries). Generally, local flows and creep are accepted as the initial mechanisms of movement of coarse clastics in the uppermost steepwalled canyon environment. Displacement of mixed muddy sediments and coarse clastics (pebbly mudstones) to lower reaches of canyon and channel is generally ascribed to debris flows, and considered to be indicative of a near-source (proximal) environment. Recent geophysical studies, however, indicate that mud or debris flows may travel over several hundred kilometers on slopes of $1^{\circ}$ or less (Moore et al., 1976; Embley, 1976). A perhaps even more equivocal type of deposit is deepsea massive or poorly graded sands. In the earlier literature of sedimentology, these usually have been explained as "fluxoturbidites," with a mechanism of transport transitional between sliding and turbulent suspension and indicative of relatively near-source channel deposits (Dzulynski et al., 1959; Stanley and Unrug, 1972). In a previous study, Moore (1974) concluded that some of the massive sands recovered by deep-sea drilling from Site 248 in the Mozambique Basin could have been transported as much as $1750 \mathrm{~km}$ over slopes as low as 1:1000, and that transport as "bed load" below a turbid flow was a possible mechanism. Moore's primary conclusion, however, was that the presence of massive sands within a turbidite sequence does not demonstrate a slope 


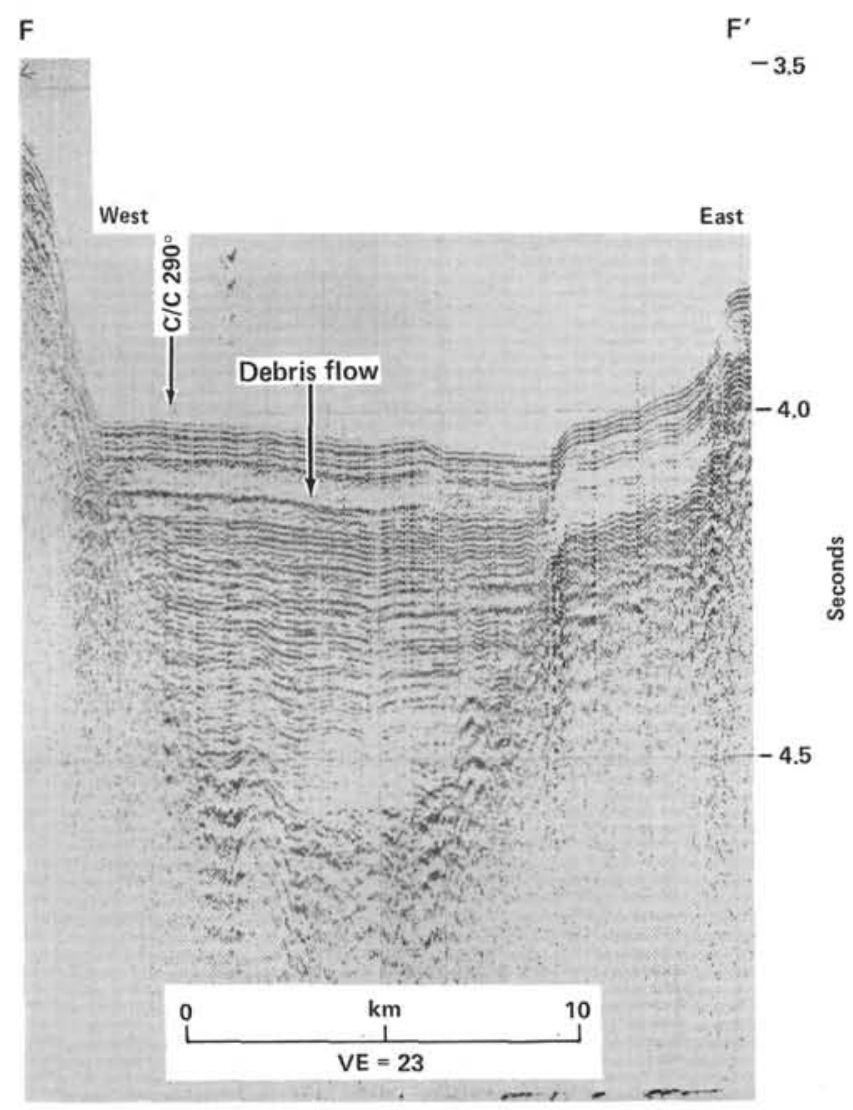

Figure 9. Seismic profile $F-F^{\prime}$, crossing the lower fan of the basin plain. The debris flow abuts the steep continental slope on the west and appears to extend across the entire basin plain. Figure 3 gives location.

or base-of-slope environment, but simply implies the presence of a source capable of supplying large quantities of sand. The redeposited sequence recovered at our Site 474 supports this conclusion. The poorly graded sand and conglomerate section penetrated has as its source Salado and Vinorama canyons, with their abundant arkosic sand supply, but the unit has been deposited as a widespread stratum on the lowermost part of the small deep-sea fan more than $65 \mathrm{~km}$ from the associated canyon sources.

The transport mechanisms for these deposits implied by our seismic-reflection data furthermore require a compound mechanism, or train of events, which displaced the materials to the present site. We believe that this sequence of events comprised a relatively slowmoving coarse-clastic debris flow from canyon source to upper mid-fan, widespread failure of over-pressured impermeable muddy sediments of the mid-fan, and a resulting highly fluid mixed debris flow and associated turbidity current that carried the displaced sediments to their present distal fan-basin floor position.

\section{ACKNOWLEDGMENTS}

We thank Drs. C. Moore and D. Stanley for their constructive reviews of our manuscript.

\section{REFERENCES}

Curray, J. R., and Moore, D. G., 1974. Sedimentary and tectonic processes in the Bengal deep-sea fan and geosyncline. In Burk, C. A., and Drake, C. L. (Eds.), The Geology of Continental Margins: New York (Springer-Verlag), pp. 617-628.

Dill, R. F., 1964. Sedimentation and erosion in Scripps submarine canyon head. In Miller, R. L. (Ed.), Papers in Marine Geology: New York (MacMillan), pp. 23-41.

Dzulynski, S., Ksiazkiewicz, M., and Kuenen, Ph. H., 1959. Turbidites in flysch of the Polish Carpathian Mountains. Bull. Geol. Soc. Am., 70:1089-1118.

Embley, R. W., 1976. New evidence for occurrence of debris flow deposits in the deep sea. Geology, 4:371-374.

Lancelot, Y., Winterer, E. L., et al., 1977. Documenting early rifting. Geotimes, 22:24-27.

Lewis, B. T. R., McClain, J., Snydsman, W. E., Lister, C. R. B., Holmes, M. L., and Heitman, C., 1975. Gulf of California IPOD site survey, final report. [unpublished manuscript]

Middleton, G. V., and Hampton, M. A., 1973. Sediment gravity flows: mechanics of flow and deposition. In Middleton, G. V., and Bouma, A. H. (Eds.), Turbidites and Deep Water Sedimentation: Soc. Econ. Paleontol. Mineral. Pacific Section Short Course.

Moore, C., 1974. Turbidites and terrigenous muds, DSDP Leg 25. In Simpson, E. S. W., Schlich, R., et al., Init. Repts. DSDP, 25: Washington (U.S. Govt. Printing Office), 441-479.

1977. Submarine slides. In Voight, B. (Ed.), Rockslides and Avalanches (Vol. 1, Natural Phenomena): New York (Elsevier), pp. 563-604.

Moore, D. G., Curray, J. R., and Emmel, F. J., 1976. Large submarine slide (olistostrome) associated with Sunda Arc subduction zone, northeast Indian Ocean. Mar. Geol., 21:211-226.

Moore, G. F., Becker, K., Bibee, L. D., Crane, K., Curray, J. R., Guerrero, J., Hawkins, J. W., Kastens, K., Kastner, M., Lawver, L. A., Melchior, J., Vacquier, V., and Williams, D. L., 1978. Gulf of California IPOD site survey, final report. [unpublished manuscript]

Shepard, F. P., and Dill, R. F., 1966. Submarine Canyons and Other Sea Valleys: Chicago (Rand-McNally).

Sibuet, J. C., Ryan, W. B. F., et al., 1979. Init. Repts. DSDP, 47, Pt. 2: Washingten (U.S. Govt. Printing Office), 25-233.

Stanley, D. J., and Unrug, R., 1972. Submarine channel deposits, fluxoturbidites and other indicators of slope and base-of-slope environments in modern and ancient marine basins. In Rigby, J. K., and Hamblin, W. D. (Eds.), Recognition of Ancient and Modern Sedimentary Environments: Soc. Econ. Paleontol. Mineral., Spec. Pub. 16:287-340.

von Huene, R., Nasu, N., et al., 1978. Japan Trench transected. Geotimes, 23:16-21. 


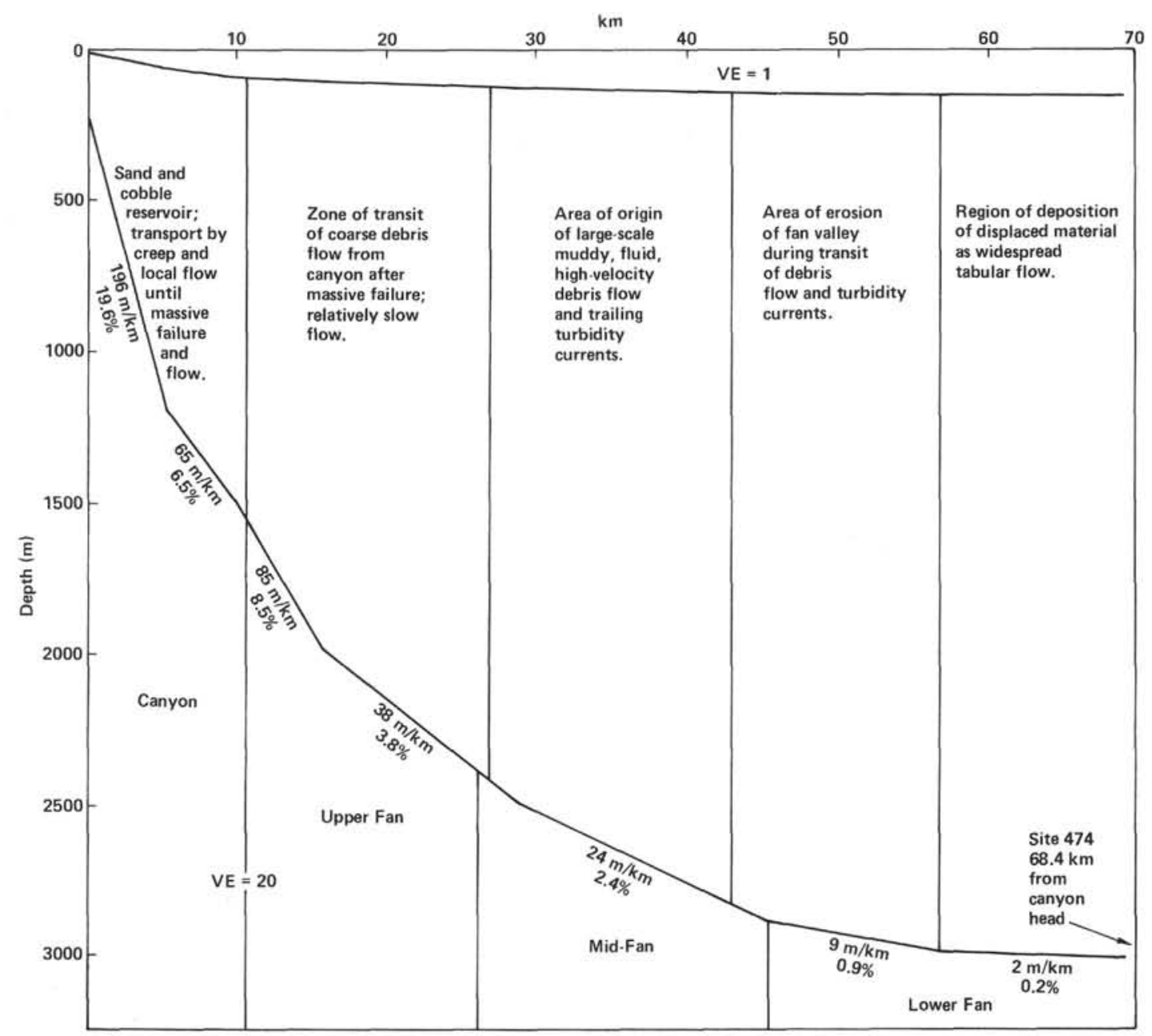

Figure 10. Salado-Vinorama Canyon and fan valley subdivisions, gradients, and summary of processes in slide sequence.

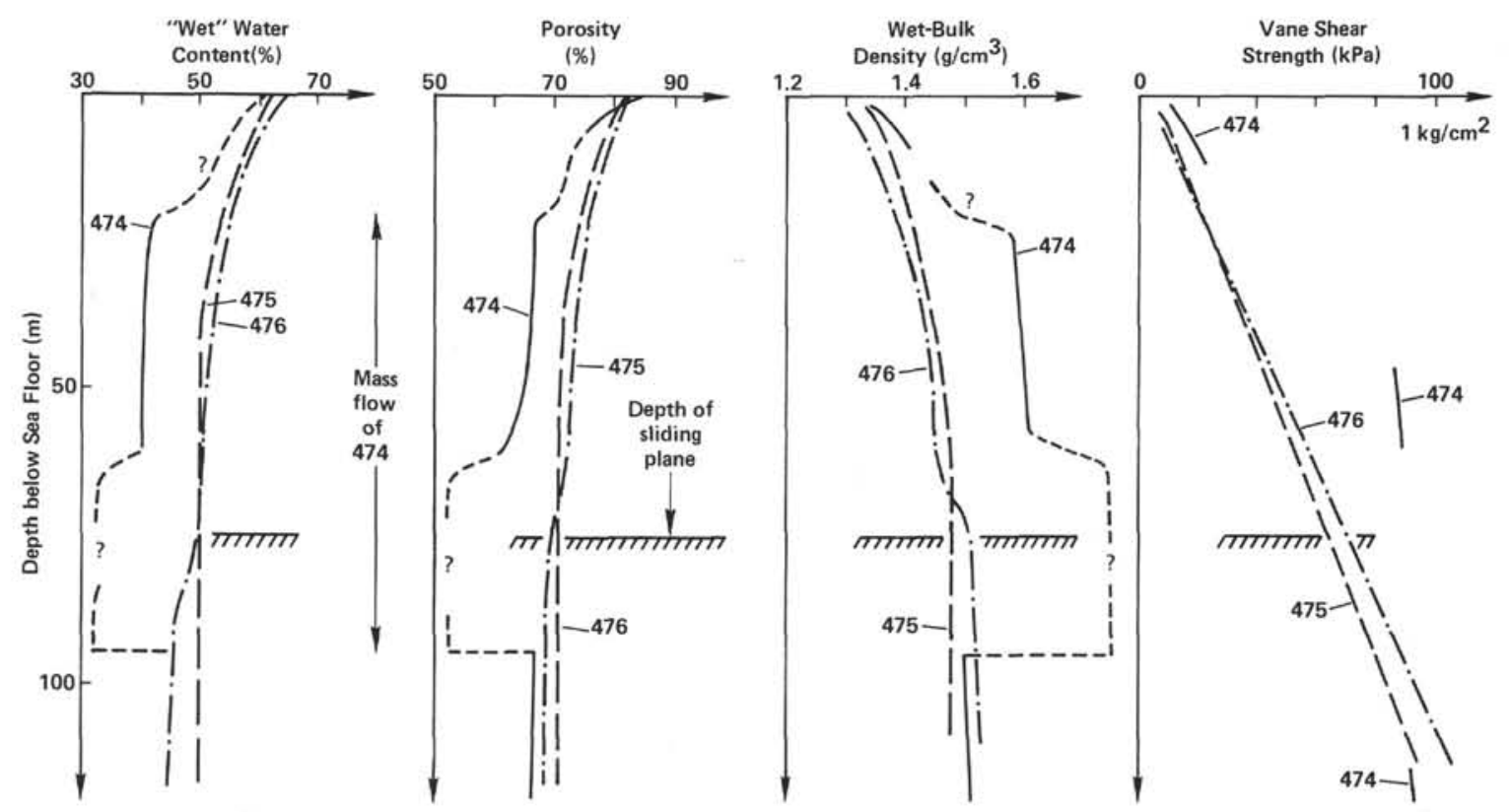

Figure 11. Physical properties from Holes 474,475 , and 476 , comparing properties within the slide mass to those within the normal slope and basin deposits. 